Discussion Paper No. 99-63

\title{
Product market competition, corporate governance
}

\section{and firm performance: An empirical analysis for Germany}

\author{
Silke I. Januszewski \\ Massachusetts Institute of Technology \\ F. Jens Köke \\ Centre for European Economic Research (ZEW), Mannheim \\ Joachim K. Winter* \\ University of Mannheim
}

December 1999

\begin{abstract}
Productivity growth has been slow in many continental European countries over the last few decades, especially in comparison with the United States. It has been argued that lack of product market competition and poor corporate governance are two of the main reasons for this phenomenon. However, predictions from theoretical models are far from unambiguous, and empirical evidence is sparse, in particular at the level of individual firms. In this paper, we aim to close this gap with an econometric analysis of firm performance in Germany. Based on a unique panel data set with detailed information on almost 400 manufacturing firms over the 1986-94 period, we find that firms operating in industries which are characterized by more intensive product market competition experience higher rates of productivity growth. We also find weak evidence for the notion that in Germany's bank-based system of internal control, ownership concentration is harmful for productivity growth.
\end{abstract}

Keywords: competition; corporate governance; productivity

JEL classification: D24; D43; G32

We wish to thank Fred Ramb for providing some of the data used in this paper and Dominik Krupp for valuable research assistance. Axel Börsch-Supan, Herbert Buscher and Dietmar Harhoff provided helpful comments on an earlier draft of this paper. Financial support by Deutsche Forschungsgemeinschaft through grant No. BO 934/7-1 and Sonderforschungsbereich 504 at the University of Mannheim is gratefully acknowledged.

\footnotetext{
* Corresponding author: Joachim K. Winter

Sonderforschungsbereich 504

University of Mannheim

D-68131 Mannheim, Germany

winter@uni-mannheim.de
} 


\section{Non-technical summary}

Productivity growth has been slow in many continental European countries over the last few decades, especially in comparison with the United States. European countries such as Germany and France have low capital performance as measured by capital productivity and various rates of return. Improving productivity is important not only for shareholder value, but also from a public policy perspective: In many countries, social security systems move away from pay-as-you-go systems to more capital-funded systems, and therefore the rate of return on capital will be even more important as a determinant of future generations' welfare than in the past.

It has been argued that lack of product market competition and poor corporate governance are the two main reasons for slow productivity growth in continental Europe. However, predictions from theoretical models are far from unambiguous, and empirical evidence is sparse, in particular at the level of individual firms. This study tries to close this gap with an econometric analysis of firm performance in Germany. Using a panel of almost 400 German manufacturing firms that covers the period 1986-94, we analyze how product market competition and corporate governance affect the growth of total factor productivity.

Our empirical approach improves on existing empirical studies on corporate governance in Germany in two important respects. First, the data set consists of listed and non-listed firms which also differ in their legal forms. Hence, our analysis is not restricted to public companies with limited liability whose shares are listed (börsennotierte Aktiengesellschaften). Second, we recognize that product market competition and corporate governance are potentially endogenous. To avoid biased regression results, we use an instrumental variables technique.

We find that firms which operate in more competitive product markets have a higher growth of total factor productivity. This suggests that an increase in the intensity of competition should result in productivity improvements. From this perspective, the ongoing integration of the European Union, for example as a result of the common market, and of world product markets are of particular importance for economic growth. In contrast to results from a similar study by Nickell et al. (1997) for the U.K., we do however not find stable effects of proxy variables for corporate governance on firm performance. There is even some evidence that in our sample, ownership concentration reduces productivity. This might be due to the fact that cross-holdings and pyramid ownership structures (which are very important in Germany) are inefficient in monitoring managers, but more research on this mechanism is needed. 


\section{Introduction}

Productivity growth has been slow in many continental European countries such as Germany and France over the last few decades, especially in comparison with the United States. Improving productivity is important not only to improve shareholder value, but also from a public policy perspective: In most countries, social security systems move away from pay-as-yougo financing and into partially or fully funded systems, and therefore the rate of return on capital will be even more important as a determinant of future generations' welfare than it has been in the past (Feldstein and Samwick, 1997, and Börsch-Supan and Winter, 1999).

Many economists argue that there are two main reasons for poor firm performance in continental European countries: lack of product market competition and poor corporate governance (see Baily and Gersbach, 1995, McKinsey Global Institute, 1997, Börsch-Supan, 1998, and Allen and Gale, 1998). A number of theoretical papers investigate the effects of competition and corporate governance on firm performance, but the theoretical predictions are far from unambiguous. Moreover, empirical evidence is sparse, in particular at the level of individual firms. In this paper, we aim to close this gap with an econometric analysis of firm performance in Germany. We use a unique panel data set with detailed information on almost 400 manufacturing firms over the 1986-94 period, and we apply an econometric approach which allows us to alleviate endogeneity problems which typically plague empirical studies of firm performance.

In order to get a preliminary understanding of productivity differences between countries, it is helpful to look at how labor, capital, and factor productivity have evolved over time. Figures 1 through 4 show productivity comparisons between the U.S. as the leading Anglo-Saxon economy and the continental European countries of Germany and France for 1970-95; the productivity estimates are taken from McKinsey Global Institute (1997). Figures 1 and 2 demonstrate that the gap in capital productivity between Germany and the U.S. has been much larger than the gap in labor productivity. Figure 3 suggests a possible reason for this: capital intensity has been higher in Germany than in the U.S., favoring relatively high labor productivity, while at the same time total factor productivity has been low. Taken together, these figures show that labor and capital productivity have been higher in the U.S. than in Germany and France throughout this entire period, leading to substantially higher total factor productivity in the U.S. (Figure 4). 
Additional empirical evidence confirms that poor capital performance in Germany, France and other continental European countries also results in low rates of return on capital (see Mueller and Yurtoglu, 1998, and Börsch-Supan, 1998). In a comparative study of investment behavior of German and U.S. firms, Nowak (1998) finds evidence for the notion that the U.S. industrial sector is more efficient in making value-enhancing investment decisions. Nowak argues that potential reasons for the fact that value generated by firm investment is so much lower in Germany than in the U.S. are differences in corporate governance and in capital productivity. Finally, sector-specific product market regulations in many European countries constrain exposure to international competition and cause firms to innovate less and rely on less efficient production processes which also reduces productivity growth (Baily and Gersbach, 1995).

There is quite a large body of theoretical work on the effects of corporate governance and product market competition on firm performance. A number of models investigate whether product market competition can improve managerial incentives and internal management control. However, their results crucially depend on assumptions on owners' and managers' preference structures, specifically on their attitudes towards risk. ${ }^{1}$ Given the importance of the issues and the inconclusive predictions from theoretical models, surprisingly little empirical work has been done so far to investigate the interaction of corporate governance and product market competition in their effect on productivity at the firm level. Nickell et al. (1997) are the first to analyze this question directly using a panel of U.K. firms. To our knowledge, there is no similar formal firm-level study of productivity growth for bank-based continental European economies, in particular for Germany, where corporate governance problems are judged to be more severe than in market-based economies such as the U.K. or the U.S. (see, e.g., Edwards and Fischer, 1994).

In this paper, we follow the approach of Nickell et al. (1997) and analyze the role of product market competition and corporate governance as determinants of productivity growth in German manufacturing firms. We restrict our attention to the manufacturing sector because productivity dynamics in service industries are much more difficult to measure and to estimate in empirical models. Our empirical approach improves on existing empirical studies on corporate governance in Germany (e.g., Cable, 1985, and Nibler, 1995) in two important respects, a

\footnotetext{
${ }^{1}$ We provide a detailed review of the theoretical and empirical literature in section 2.
} 
very broad sample of firms, and an econometric technique which controls for endogeneity problems.

Our empirical analysis is based on a new and detailed panel of 364 German manufacturing firms covering the 1986-94 period. In contrast to all previous studies on firm behavior in Germany, we do not restrict our attention to firms listed on the stock exchange. In our sample, the number of these non-listed firms is substantial, reflecting their important role in the German economy. Almost $20 \%$ of the firms in our sample are non-listed and run in the legal form of a Gesellschaft mit beschränkter Haftung $(\mathrm{GmbH})$, i.e. a private company with limited liability. The remaining firms in the sample are run as a Aktiengesellschaft (AG), i.e. a public company with limited liability, and of these $50 \%$ are not listed on the stock exchange. In addition to standard measures of productivity derived from the companies' balance sheets, our data set also contains information on the degree of competition in the firm's product market, measured at the four-digit industry level, and on ownership structure. ${ }^{2}$

In contrast to much of the existing empirical literature on corporate governance (excluding the work by Nickell et al., 1997), our econometric approach allows to control for the endogeneity of both product market competition and corporate governance. ${ }^{3}$ We estimate productivity growth equations (derived from a constant returns Cobb-Douglas production function) using a fixed-effects generalized method of moments estimator introduced by Arellano and Bond (1991). While such an approach certainly does not solve all potential econometric problems, we believe that it is a step in the right direction. Our main finding is that firms operating in industries which are characterized by more intensive product market competition tend to see higher rates of productivity growth. Direct effects of our proxy variables for corporate governance on productivity are, however, weak.

The remainder of this paper is structured as follows. In section 2, we review the existing theoretical and empirical literature on the relationship between product market competition, corporate governance and firm performance. Section 3 presents our empirical model and the GMM estimation procedure, and section 4 contains our estimation results. Section 5 concludes.

\footnotetext{
${ }^{2}$ Köke (1999) provides additional details on the liability status and the ownership structure of the firms in our dataset.

${ }^{3}$ Börsch-Supan and Köke (2000) provide a detailed discussion of endogeneity problems encountered in empirical studies of corporate governance.
} 


\section{Existing literature on the determinants of firm productivity}

The aim of corporate governance is to overcome incentive problems generated by the separation of ownership and control in non-owner operated firms. The main mechanisms by which corporate governance works are internal control and management compensation, designed to align managers' incentives with the owners' goals (see Shleifer and Vishny, 1997). However, corporate governance may not always be effective. Factors like concentration of share ownership, capital structure and board structure determine the owners' incentives to incur the cost of installing effective governance mechanisms.

Even in the presence of weak corporate governance, fierce product market competition may act to align managers' goals with the aim of efficient production; Allen and Gale (1998) provide a review. ${ }^{4}$ For example, Holmström (1982) and Nalebuff and Stiglitz (1983) show in a setting with cost functions which are stochastic but identical across agents (or firms, respectively) that perfect competition reveals full information to the owners about the realization of common cost shocks. In this case, relative performance evaluation can induce optimal management performance. Hart (1983) compares two situations with independent and with positively correlated cost functions, respectively, showing that, when costs are correlated, competition reduces the amount of managerial slack. However, Scharfstein (1988) shows that Hart's results depend on the extent of managers' assumed risk aversion. Scharfstein presents a model which is similar to Hart's but assumes a different utility function. The result is contrary to Hart's: Increased product market competition leads to more slack.

Hermalin (1992) identifies four mechanisms of the influence of product market competition on management performance. These are an income effect of reduced profits in a more competitive environment, a risk-adjustment effect if profit risks vary with the degree of competition, an effect of change in returns to managerial effort, and the effect of improved information in the presence of more rival firms. None of these effects is unambiguous in the sense of either reducing or increasing agency costs with increased competition, but Hermalin shows that if the income effect is positive (i.e., if agency goods are normal) and dominates the other three effects, then agency costs decrease with intensified competition. Schmidt (1997) analyzes the impact of competition on the threat of bankruptcy and resulting managerial effort.

\footnotetext{
${ }^{4}$ See Shleifer and Vishny (1997) for a more skeptical view.
} 
He finds that competition increases the likelihood of bankruptcy for inefficient firms and should, therefore, improve management performance.

In summary, theoretical analyses of the effects of product market competition and corporate governance on firm performance do not provide us with a clear prediction for the sign of these effects. Turning to the existing empirical literature, Caves and Barton (1990), Caves (1992), Green and Mayes (1991), Blundell et al. (1995) and Nickell (1996) present some evidence that increased product market competition is associated with higher firm productivity or higher productivity growth. The evidence on the effect of shareholder control on productivity is mixed; see Short (1994) for a survey of the empirical literature on ownership and firm performance. For example, Leech and Leahy (1991) find that better ownership control improves firm performance. ${ }^{5}$ In a careful empirical study of the relationship between managerial ownership and firm performance, Himmelberg et al. (1999) stress the fact that both ownership and performance are determined endogenously by changes in the firm's contracting environment. Controlling for observed firm characteristics and firm fixed effects, they find no evidence for the notion that changes in managerial ownership affect firm performance.

Little empirical work has been done so far on the interaction of corporate governance and product market competition in their influence on firm performance. Several authors, however, have investigated the interaction of product market competition and firm capital structure. This work may be informative for the topic we investigate since, following Jensen (1986), a high degree of leverage is also regarded as a device of disciplining management. Chevalier (1995a) finds that highly leveraged firms are weak competitors in the product market. However, this result also depends on the debt levels of other competitors (Chevalier, 1995b). Phillips (1995) finds the same result as Chevalier (1995a) for three industries, but the opposite effect for a fourth industry. The evidence presented in Kovenock and Phillips (1997) indicates that the interaction of firm leverage and product market competition is important in determining future firm performance. The results of Zingales (1998) support these findings. All these empirical studies use data from the U.S.

Nickell et al. (1997) estimate the effect of product market competition, shareholder control, and debt levels on firm-level productivity growth in the U.K., including interaction terms. Their results show a positive influence of product market competition, ownership control, and

\footnotetext{
${ }^{5}$ Leech and Leahy (1991) use a measure of the degree of ownership control proposed by Cubbin and Leech (1983). We use the same measure in our empirical analysis; see section 3.
} 
financial pressure on productivity growth. In addition, they find evidence that both competition on product markets and financial pressure can substitute for internal control. In a similar framework, Nickell and Nicolitsas (1999) investigate how financial pressure affects firm behavior, also using data from the U.K. They find that an increase in financial pressure has a large negative effect on employment while it has a small positive effect on productivity.

To our knowledge, there are no empirical studies on the interaction of product market competition and corporate governance available for continental European countries. As many studies (e.g., Prowse, 1994, Edwards and Fischer, 1994) argue that control is much tighter in marketbased than in bank-based economies, it will be interesting to compare the findings Nickell et al. (1997) obtained for the U.K. - a market-based economy - with our empirical findings for Germany, an economy with a bank-based system of corporate governance and a complex ownership structure characterized by cross-holdings and poor external control structures (see, among others, Köke, 1999, for descriptive evidence on ownership structures in German manufacturing).

\section{An empirical model of productivity growth}

In this section, we present our empirical model of productivity growth. Our analysis follows the approach by Nickell (1996) and Nickell et al. (1997). The empirical model is based on a productivity growth equation derived from the firm's production function, augmented with a set of variables which capture the influence of product market competition and corporate governance on productivity growth. There are two reasons for estimating growth equations. First, measurement problems are much more severe for levels equations than for growth equations. Second, measures of industry competition might well be endogenous with respect to the productivity level, but we would argue that this endogeneity problem is less severe if productivity growth is the dependent variable. Using the general framework described in this section, we also estimated productivity level equations and obtained results which indicate that endogeneity problems are of some practical relevance, while the results reported in Section 4 demonstrate that in growth equations, endogeneity problems can be controlled with a suitable instrumental variable estimation technique.

Specifically, we assume a constant-returns Cobb-Douglas production function, and we estimate the augmented growth version of this production function using a fixed-effects, generalized method-of-moments (GMM) estimator to account for the potential endogeneity of the explanatory variables. We augment the productivity growth equation with a number of time- 
varying, firm or industry specific variables that capture product market competition and corporate governance. ${ }^{6}$ Nickell also includes changes of market share as a competition variable. As we do not have data on market shares, all our variables are measures of the level of competition. To measure product market competition, we use four variables. First, to control for business cycle effects on competition, we use two-digit industry-level capacity utilization rates $(C Y C L E)$. In our dataset, we have two measures of market concentration at the four-digit industry level, the combined market share of the six largest firms in the industry (CRO), and the industry's Herfindahl index $(H H I)$. We do acknowledge, however, that these measures do not reflect all possible facets of competition, namely potential entry and firm conduct. In the regressions reported below, we include only the concentration ratio since both measures are highly correlated. Our results are not sensitive to this choice.

We also include total rents earned by the firm, normalized by total sales, which can be interpreted as an ex post measure of market power (RENTS). Finally, in some specifications, we control for corporate governance and shareholder control using a measure proposed by Cubbin and Leech (1983). Specifically, we interact the RENTS variable with a dummy variable CONTROL which takes the value 1 if control is tight, i.e., if the largest shareholder, based on a probabilistic voting model, wins a decision with a probability of $95 \%$. Note that in this framework, other measures that might affect productivity growth such as the financial pressure variables considered by Nickell et al. (1997) could also be included. We experimented with such specifications as well, but we did not obtain robust results and therefore do not report results. $^{7}$

We now describe the empirical model and the estimation procedure in more detail. The starting point of our analysis is a Cobb-Douglas production function with labor, $N$, and capital $K$, as production factors. $Y$ is output, $A$ is total factor productivity. Firms are indexed by $i$, time periods by $t$. Upper-case letters represent levels, lower-case letters logarithms. The CobbDouglas production function then is

$$
Y_{i t}=N_{i t}^{\beta_{N}} K_{i t}^{\beta_{K}} A_{i t}
$$

\footnotetext{
${ }^{6}$ A detailed description of these product market and corporate governance variables, and of all other variables used in our empirical analysis, can be found in the data appendix.

${ }^{7}$ We return to this issue in section 4 where we present our empirical results.
} 
We transform this production function in several steps. We take logs and impose constant returns to scale by setting $\beta_{N}=\left(1-\beta_{K}\right)=: \beta_{0}$; in preliminary regressions, we ascertained that constant returns are a valid assumption in our sample. We include lagged output as an explanatory variable to allow for endogenous persistence, using a weight $\lambda$. Finally, we allow for unobserved firm effects, $\alpha_{i}$, and include an error term, $\varepsilon_{i t}$, which is assumed to be uncorrelated over time. This yields our basic log-linear empirical production function:

$$
y_{i t}=\lambda y_{i t-1}+(1-\lambda) \beta_{0} n_{i t}+(1-\lambda)\left(1-\beta_{0}\right) k_{i t}+a_{i t}+\alpha_{i}+\varepsilon_{i t} .
$$

Next, we convert the production function (2) into its growth form by taking first differences; this will also remove firm fixed effects, $\alpha_{i}$. We then parameterize productivity growth (i.e., the first difference of total factor productivity) as a linear function of time effects, a contemporaneous industry-specific business cycle proxy variable, and the set of lagged time and firm or industry specific variables which capture differences in product market competition and corporate governance ${ }^{8}$ :

$$
\begin{aligned}
& a_{i t}-a_{i t-1}=\left(\alpha_{t}-\alpha_{t-1}\right)+\beta_{1} C Y C L E_{i t}+\beta_{2} C R 6_{i t-1}+\beta_{3} H H I_{i t-1}+\beta_{4} \text { RENTS }_{i t-1} \\
& +\beta_{5}(\text { RENTS } \cdot \text { CONTROL })_{i t-1} .
\end{aligned}
$$

Using specification (3), exploiting constant returns to scale and setting $\beta=(1-\lambda) \beta_{0}$, we finally obtain the differenced growth version of the constant returns Cobb-Douglas production function (1):

$$
\begin{aligned}
\Delta\left(y_{i t}-k_{i t}\right)= & \Delta \alpha_{t}+\lambda \Delta\left(y_{i t-1}-k_{i t}\right)+\beta^{*} \Delta\left(n_{i t}-k_{i t}\right)+\beta_{1} C Y C L E_{i t}+\beta_{2} C R 6_{i t-1} \\
& +\beta_{3} H H I_{i t-1}+\beta_{4} \operatorname{RENTS}_{i t-1}+\beta_{5}(\operatorname{RENTS} \cdot \operatorname{CONTROL})_{i t-1}+\Delta \varepsilon_{i t} .
\end{aligned}
$$

This equation could, in principle, be estimated using standard least-square panel data methods. However, as we suspect that explanatory variables such as product-market competition and corporate governance are endogenous with respect to productivity growth, we use an instrumental variables method to estimate this equation. Lacking proper instruments, we are restricted to using lagged endogenous variables as instruments. Specifically, we apply the generalized method of moments (GMM) estimator proposed by Arellano and Bond (1991). Recall that firm-specific effects are removed by forming first differences. In such a model, endoge-

\footnotetext{
${ }^{8}$ While in our regressions, the only corporate governance variable considered is, due to limited data availability, shareholder control, other variables could of course be entered in such an equation as will.
} 
nous variables lagged two or more periods will be valid instruments provided there is no serial correlation in the time-varying component of the error terms in equation (2). To ensure that this condition is met, we test for serial correlation in the first difference residuals. We also test for instrument validity using a Sargan test of over-identifying restrictions. Finally, the standard errors and $t$-tests we report are asymptotically robust to general heteroskedasticity. ${ }^{9}$

While in principle, this approach can deal with potential endogeneity problems in our application, there is an important caveat. Blundell and Bond (1998) show that in autoregressive models with persistent series, the first-difference estimator can be subject to finite sample bias as a result of weak instruments, and that these biases could be greatly reduced by the inclusion of levels equations in a GMM system estimation procedure (see, e.g., Bond et al., 1999). We do not estimate a model with equations in both levels and first differences because of the structure of our empirical model - as noted before, we assume that the level of competition influences productivity growth, following Nickell (1996) and Nickell et al. (1997). Hence, while our formulation has the advantage that we do not have to compare levels of productivity across firms and industries, but only changes in productivity, it has the disadvantage of potentially weak instruments (which is, however, difficult to assess in a given empirical application).

All regressions reported in the next section include interacted time and industry dummies (for every year and for five one-digit industries). ${ }^{10}$ We use all available lags of $y, n$, and $k$ as instruments (i.e., from $t$ - 2 up to $t-9$, depending on spell length). The other explanatory variables are instrumented as well (with the exception of CR6, since its time-varying component is small, and CONTROL which does not vary over time at all). Endogeneity concerns are most relevant with respect to the rents variable that measures ex post market power. In the estimates reported below, we use one lag of RENTS as instruments. We check for robustness of this specification using zero and two lags of RENTS, and find that the results are not sensitive to these variations. ${ }^{11}$ We also experimented with different definitions of the rents variable, specifically those used by Nickell (1996), and with various measures of capital stock assuming different rates of depreciation and using the inventory method described in Wadhwani and

\footnotetext{
${ }^{9}$ The GMM estimates reported in this paper are computed using DPD98 for GAUSS (see Arellano and Bond, 1998).

${ }^{10}$ We do not include two-digit industry dummies because, in the smaller sample with ownership information, we do not have sufficient observations per two-digit industry.

${ }^{11}$ If we use more than two lags, however, the hypothesis of over-identifying restrictions cannot be rejected.
} 
Wall (1986). The results, in particular statistical significance and sign of the rents variable, turned out not to be sensitive to any of these robustness checks.

\section{Empirical results}

For estimation, we use an unbalanced panel of 364 manufacturing firms with 2217 observations covering the 1986-94 period; we refer to this panel as the full sample. There is also a subsample of 136 firms (935 observations) for which we have ownership information. The construction of these samples and the definitions of the variables we use in our regressions are detailed in the data appendix.

The first model we report was estimated using the full sample of 364 firms in order to assess the impact of product market competition on total factor productivity growth, not including ownership variables (see table 1). In order to check the robustness of the production function estimates, we first report a specification of the productivity growth equation which does not include competition variables (column 1). When we include competition variables (column 2), the input coefficient changes little, whereas the lagged output variable has a smaller coefficient in this specification.

We find a highly significant negative impact of the one period lagged RENTS variable on current productivity growth. Recall that RENTS is an inverse measure of competition - the more intensive competition on product markets, the smaller the rents that firms can appropriate. Therefore, we cannot reject the hypothesis that competition has a positive effect on productivity growth. The concentration ratio $C R 6$ is, however, not significantly different from zero. (The same is true if we include the industry Herfindahl index instead of the concentration ratio; results are not reported.) The business cycle proxy is also insignificant. These insignificant coefficients might be due to the fact that the interacted time and industry dummies absorb most of the variation in these industry-level variables. Also, as reported in the data appendix, we were not able to assign competition variables to firms perfectly because we only have industry codes for the firms' primary product industries.

In the third and fourth columns of table 1, we report results of the same regressions as in column 1 and 2, respectively, now using the smaller sample for which we have ownership data. Here, we again find a highly significant negative effect of RENTS, and insignificant effects for the concentration ratio and the business cycle proxy. As the coefficient estimates are qualitatively similar to those obtained for the full sample, we conclude that the reduced sample of firms for which we have ownership information should still provide reliable results. 
Note that all versions of our GMM model are generally supported by the standard battery of specification tests. The Sargan tests do not reject the hypothesis of instrument validity. Also, the tests for serial correlation in the first difference residuals do not reject our specification: As required, the first-order serial correlation of the (differenced) error terms is negative, and the second-order correlation is zero. Finally, in all specifications we report, the slope coefficients and the sets of time and industry dummy variables are jointly significant according to our Wald tests. In general, our results for the impact of competition (as measured by the lagged rents variable) are also robust against variations of the lag length chosen for the instruments.

We now turn to the effects of corporate governance and ownership structure on productivity growth. Table 2 reports regressions that augment the specification in column 4 of table 1 with an interaction term of the RENTS variable with the Cubbin and Leech index of ownership control (CONTROL), which is equal to one when ownership is highly concentrated (which is the case for $62.5 \%$ of the observations). Here, we obtain a negative sign of the interacted term which is significant at the $10 \%$ level. The RENTS variable, in contrast, is insignificant. These findings indicate that competition has a positive effect on productivity growth (only) for those firms which have concentrated ownership of their shares. When we do not include an interaction term, but the control dummy directly, the effect of concentrated ownership is negative and significant at the $5 \%$ level (table 2, column 2). If we introduce both variables individually and an interaction term, the model is rejected by our specification tests. ${ }^{12}$

These results do not support the notion that, in the bank-based German economy, owners with a dominant stake in the firm will enforce value maximization (here reflected in stronger productivity growth). There are several potential explanations for this finding. Most importantly, in our data set, high levels of ownership control might be associated with long control chains and pyramid structures (see Köke, 1999) which lead to inefficiencies. In some instances, concentrated ownership might also be associated with high levels of managerial ownership, so poor performance might be due to incentive problems known as managerial entrenchment (Fama and Jensen, 1983). However, we lack the data to test formally for these effects.

\footnotetext{
${ }^{12}$ Note that we obtain similar results if we use an alternative measure of control instead of the Cubbin-Leach index, namely a dummy variable for the fact that the largest shareholder owns more than $50 \%$ of the shares (which is the case for $57.1 \%$ of all firms); these regressions are not reported here.
} 
We also find a significant effect of product market competition on productivity growth; this effect is, however, only significant for those firms which are under concentrated ownership. Our findings are in sharp contrast to those of Nickell et al. (1997) for the market-based U.K. system, and they indicate that the concentration of ownership may be harmful for productivity growth of German firms. Taken together, these observations add weight to existing evidence on the differential performance of Anglo-Saxon and continental European firms obtained in aggregate or industry-level studies.

In addition to the specifications reported here, we also experimented with including a (lagged) financial pressure variable as in Nickell et al. (1997) or Nickell and Nicolitsas (1999), defined as the ratio of interest paid and the sum of profit before taxes, depreciation, and interest paid. In some specifications, we found a significant negative impact of financial pressure on productivity growth. The negative effects we found were, however, not robust across specifications (i.e., the lag structure); we therefore do not report these results. Note that Nickell et al. (1997) and Nickell and Nicolitsas (1999) obtained a (small) positive effect of financial pressure on productivity growth using U.K. data. For Germany, a negative effect of financial pressure on productivity growth would not be entirely unreasonable - such a finding might, again, be related to the dominance of banks in firm finance in Germany. ${ }^{13}$

\section{Conclusions}

In this paper, we presented an empirical analysis of the effects of product market competition and ownership control on total factor productivity growth using a panel data set of almost 400 German manufacturing firms over the 1986-94 period. We found a significantly negative impact of rents appropriated by firms, indicating that product market competition has a positive impact on productivity growth. The effects of industry concentration measures were insignificant, but this may be due to measurement problems (i.e., the fact that one cannot assign such industry-level variables perfectly to firms). Using a smaller sub-sample of firms for which we also have information on ownership structure, we found weak evidence that competition has a positive effect on productivity growth for those firms which have concentrated ownership of their shares. In addition, we found evidence that concentrated ownership has a negative direct impact on productivity growth. Taken together, these findings suggest that product market competition can compensate for the negative influence of dominant owners. 
In our empirical model, the influence of competition is measured by (lagged) economic rents, a firm-specific ex post measure. Because of the fact that even lagged economic rents are endogenous, we used an instrumental variable technique to control for potential endogeneity. The negative impact of lagged rents on productivity growth turned out to be extremely robust against various alternative specifications. We are therefore confident that even though the GMM method we apply might be subject to small sample biases, our main findings are reliable.

Our results have some strong policy implications. Most importantly, our findings add empirical support to some well-known hypotheses about the welfare effects of product market competition (e.g., Allen and Gale, 1998, and Börsch-Supan, 1998). The implications for competition policy, in particular within continental Europe and the European Union at large, are obvious - increased competition in the common market should have positive effects on productivity growth. Regarding the effects of corporate governance (i.e., ownership structure), there is clearly more research needed, and we make some suggestions below. Our results do, however, suggest that in Germany, concentrated ownership does not imply tighter control and higher productivity growth. Rather, in Germany's bank-based system of internal control, concentrated ownership seems to be even harmful to firm performance.

We end this paper by discussing a few unresolved issues, and we indicate directions for future research. First of all, it might come as a disappointment that other than ex post rents, all variables which measure industry-level competition were generally not significant. However, this might be due to severe measurement problems: As noted before, the industry classification of firms at the four-digit level according to their primary product is quite unreliable. Also, concentration measures can only indicate potential, not actual competition, whereas ex post rents reflect the effects of the market power that a firm can actually exert. We would also argue that not much progress can be made by considering alternative measures of the level of competition in a given industry. It seems more promising to look at changes in competition triggered by exogenous events, but this approach is more suitable for industry-level studies than for a sector-wide panel study of manufacturing firms. While there are, to our knowledge, as yet no such case studies available for Germany, recent product market deregulations in the German

\footnotetext{
${ }^{13}$ For example, Börsch-Supan (1998) reports that in Germany, creditors do not use their control potential to improve firm productivity.
} 
telecommunications and energy markets, and in the European Union at large, might provide data suitable for empirical studies in the future.

While we do not think that, for Germany, much better measures of industry-level competition can be found, the effects of ownership structure and corporate governance should be explored further, and a number of measurement problems need to be resolved.

First, it would be interesting to investigate what types of owners (private owners, other firms, mutual or pension funds, banks, etc.) have the ability to ensure high productivity growth (see Admati et al., 1994, for a theoretical model of a dominant owner's influence, and Black, 1998, for a review of existing empirical work). Second, ownership structures are complex in reality. For example, pyramid structures and cross-holdings are quite common in Germany, and these structures can hardly be captured in a dummy variable such as the Cubbin-Leech measure. Also, we consider only direct ownership which might be very different from ultimate ownership. Köke (1999) presents some descriptive evidence on the complexity of ownership structures among both listed and non-listed manufacturing firms in Germany. Third, changes in the ownership structure should have important effects on productivity growth, although these changes are endogenous as well (see Himmelberg et al., 1999, for a careful analysis). It should be worthwhile to identify changes of ownership structure and friendly take-overs in a panel of German firms and investigate their effects on firm performance (hostile take-overs are very rare in Germany). Fourth, ownership structure does not only affect productivity growth, but also firm survival and market exit decisions (e.g., Winter, 1999). To our knowledge, there are as yet no empirical studies that investigate any of these issues in a systematic fashion for Germany, and they are well worth being explored in future research.

Finally, there might be much more complex interactions of ownership structures, board structure, capital structure, and firm performance (e.g., Agrawal and Knoeber, 1996). For example, as noted at the end of the previous section, we checked whether financial pressure has any effect on productivity growth in our empirical model, but we did not find stable results. If anything, we obtained weak evidence for a negative effect of financial pressure - in contrast to the (small) positive effect reported by Nickell et al. (1997) and Nickell and Nicolitsas (1999). A negative effect of financial pressure on productivity growth is, however, not entirely unreasonable in Germany's bank-based system of corporate governance (see Harhoff and Körting, 1998, for an analysis of lending relationships in Germany). Direct measures of bank influence should therefore be used to investigate the role of banks in future empirical work. 


\section{Data appendix}

This study combines several sources of data. Data on the firms' output and factor inputs are obtained from the Bilanzdatenbank (balance sheet database) compiled by Hoppenstedt, a German publishing company specializing in company and stock market information. This commercially available database contains data from balance sheets and from profit and loss statements of large German firms; in addition, it describes the structure of firms' tangible assets. For each legal entity submitting data, about 1000 variables from balance sheets and profit and loss statements are available. For most firms, balance sheet data appear in unconsolidated form, but a substantial number of firms also provide consolidated data. These firms are, on average, larger and almost half of them (42.2\%) are listed on the stock exchange. In 1998, the Hoppenstedt database contained a total of 54,856 observations for the years 1980-1998. Data on the ownership structure of firms are taken from the Wegweiser durch deutsche Unternehmen (guide through German companies) published annually by (formerly) Hypobank, one of the largest German commercial banks. Finally, data on the structure of firms' output markets were taken from a biennial report by the German federal anti-trust commission (Monopolkommission, 1996).

We restrict the empirical analysis to the period 1986-1994. All data used in this study refer to the Federal Republic of Germany, i.e. to West Germany before 1990 and to East and West Germany from 1990 on. We choose 1986 as the starting year of our analysis because this is the year when new accounting rules (the 1986 revision of $\$ 289$ HGB) took effect, which makes data before and after the change incomparable. The last period of our investigation, 1994, is again due to reasons of data comparability: After 1994, the classification of firms into four-digit industries has changed.

In the Hoppenstedt database, the highest degree of consolidation is the world level for which we have 5758 observations over the 1986-1994 period. This set of observations is the starting point of our sample selection procedure (summarized in table A1). We focus on firms with limited liability because within these firms, agency conflicts should be most severe (Berle and Means, 1932). This restriction reduces the sample to 5658 observations. Eliminating observations for non-manufacturing firms leaves a sample of 3272 observations. Since the econometric approach used in this study requires a minimum of three consecutive observations for each firm and after eliminating missing data, the size of the final sample is reduced to 2217 observations for 364 firms. 
In contrast to all previous studies on corporate governance in Germany, we do not restrict our attention to firms listed on the stock exchange. Table A2 lists the numbers of firms and observations in the full sample and in the subsample for which we have ownership information. The numbers are substantial: More than $20 \%$ of the firms are run in the legal form of the $\mathrm{GmbH}$ and non-listed, and more than $50 \%$ of the remaining firms which are run aktiengesellschaft (AG) are not listed on the stock exchange. We have detailed ownership information on about one third of the firms covered. In those specifications which use information on ownership structure, the sample size is further reduced to 935 observations (136 firms).

The average number of observations per firm is about seven: on average, there are 6.63 firmyears in the unrestricted sample and 7.29 firm-years in the sample for which we have ownership information (Table A3). Table A4 shows that observations are evenly distributed over most years, exceptions being the years 1986 and 1987. We have fewer observations in these years because firms had some discretion in adopting the new accounting standards; some firms reported under the new rules as late as 1988.

The variables we use in our econometric analysis are constructed in analogy to Nickell et al. (1997) wherever possible, in order to allow direct comparison with their results. Minor differences occur because we do not have stock market data to calculate the risk premium which Nickell et al. include in their cost of capital variable. Since our sample contains a large number of firms not listed on the stock exchange, we could not obtain a market risk premium for the entire sample. However, we feel that this limitation is compensated by the large number of non-listed firms in the sample. We also choose a slightly different method to construct our capital stock variable (see below).

Table A5 provides descriptive statistics of the variables used in the empirical analysis. All variables are appropriately deflated and measured in prices of 1991. Sources of price and cost indexes and other aggregate variables are given below, together with details on how we constructed each variable used in our empirical analysis.

\section{Output}

The firm's output, $Y$, is defined as total sales, deflated using a two-digit industry-specific producer price index published by the Federal Statistical Office (Statistisches Bundesamt, Fachserie 17, Reihe 2, 1998). 


\section{Labor}

The firm's labor input, $N$, is defined as the total number of employees.

\section{Capital stock}

The firm's capital stock, $K$, is defined as replacement costs of tangible assets including machines, buildings and land, deflated using a combined input price index for capital goods and land, weighted by their empirical distribution (Statistisches Bundesamt, Fachserie 17, Reihe 2, and Fachserie 17, Reihe 4, 1998). Replacement costs of capital are calculated using the method of Bond et al. (1999). They adjust the historical cost values for inflation and then apply a perpetual inventory method with a constant annual depreciation rate of $8 \%$. Specifically, $p_{t} K_{t}=(1-\partial) p_{t-1} K_{t-1}\left(\frac{p_{t}}{p_{t-1}}\right)+p_{t} I_{t}$,

where $K_{t}$ is the capital stock, $p_{t}$ is the price index for capital goods, $I_{t}$ is real investment and $\delta$ the depreciation rate. The starting value is the net book value of tangible assets, adjusted for inflation in previous years. ${ }^{14}$

\section{Business cycle proxy}

To control for business cycle effects, we use a proxy variable, CYCLE, which is a surveybased index of capacity utilization at the two-digit industry level. This index is part of the ifo Geschäftsklima and was obtained from the ifo Institut für Wirtschaftsforschung, München.

\section{Product market concentration}

The concentration index, $C R 6$, is a competition measure, defined as the sum of the six largest shares in the firm's product market (defined by four-digit output classes). These data are taken from a biennial report by the Germany federal anti-trust commission (see Monopolkommission, 1996). These data are not fully comparable before and after 1994, when a change in industry classification occurred. Note that we cannot assign this competition measure perfectly to each firm for two reasons. First, for the construction of this measure, the Anti-trust Commission uses information on firms' sales in individual market segments. Hence, there are sev-

\footnotetext{
14 We also experimented with capital stocks measures constructed following the approach proposed by Wadhwani and Wall (1986); this is also the method used by Nickell et al. (1997). They do not assume a constant rate of depreciation but also apply a perpetual inventory method. We also experimented with annual depreciation rates of $4 \%$ and $12 \%$. Our estimation results turned out to be robust against these alternative methods.
} 
eral competition measures for each firm depending on sales structure. Unfortunately, our main source of data, the Hoppenstedt database, assigns firms only to one industry, the primary product market. Hence, our competition measure may contain some classification error for large firms. Second, the classification of industries used by the Anti-trust Commission differs from the Standard Industry Classification (SIC) used in the Hoppenstedt database. Therefore, we had to assign some firms on an individual basis.

\section{Industry concentration}

The four-digit industry Herfindahl index, HHI, is our second competition measure, again taken from Monopolkommission (1996). The same remarks apply.

\section{Degree of market power}

We use rents (RENTS) earned by the firm as an ex post measure of the degree of competition. The rents variable is defined as total sales less labor and capital costs, normalized by sales. ${ }^{15}$ Costs of capital are defined as the product of capital stock and user costs of capital which are, in turn, defined as the sum of the depreciation rate $(\delta=0.08)$ and the real interest rate measured as the difference of the rate of return on 10-year government bonds and the inflation rate.

\section{Degree of control}

The degree of owner control, CONTROL, is measured by the index suggested by Cubbin and Leech (1983) and Leech and Leahy (1991). This measure is based on a probabilistic voting model. The dummy variable CONTROL takes the value 1 if the largest shareholder wins a decision among the owners with the probability of $99 \%$. It is calculated using $\Phi\left(\frac{P_{i}}{\sqrt{H_{i}-P_{i}^{2}}}\right)$ as the critical value of the standard normal distribution with $P_{i}$ representing the largest share, $H_{i}$ the Herfindahl index and $\Phi$ being the normal cumulative distribution function.

\footnotetext{
${ }^{15}$ Our definition of the rents variable is different from, and more natural than, the one used by Nickell (1996) and Nickell et al. (1997). In these papers, rents are defined as the sum of profit before taxes, depreciation, interest paid, and costs of capital, normalized by sales.
} 


\section{References}

Admati, A. R., P. Pfleiderer and J. Zechner (1994), Large Shareholder Activism, Risk Sharing, and Financial Market Equilibrium. Journal of Political Economy 102, 1097-1130.

Agrawal, A. and C. R. Knoeber (1996), Firm Performance and Mechanisms to Control, Journal of Financial and Quantitative Analysis 31 (September), 377-397.

Allen, F. and D. Gale (1998), Corporate Governance and Competition, mimeo, University of Pennsylvania and New York University.

Arellano, M. and S. Bond (1991), Some Tests of Specification for Panel Data: Monte Carlo Evidence and an Application to Employment Equations, Review of Economic Studies 58, 277-297.

Arellano, M. and S. Bond (1998), Dynamic Panel Data Estimation Using DPD98 for GAUSS. Unpublished manuscript, CEMFI, Madrid, Nuffield College, Oxford, and Institute for Fiscal Studies, London.

Baily, M. and H. Gersbach (1995), Efficiency in Manufacturing and the Need for Global Competition, Brookings Papers on Economic Activity: Microeconomics, 307-347.

Berle, A. A. and G. C. Means (1932), The Modern Corporation and Private Property, New York.

Black, B. (1998), Shareholder activism and corporate governance in the United States, in: P. Newman (ed.): The New Palgrave Dictionary of Economics and Law, London.

Blundell, R. and S. Bond (1998), Initial Conditions and Moment Restrictions in Dynamic Panel Data Models, Journal of Econometrics 87, 115-143.

Blundell, R., R. Griffith and J. van Reenen (1995), A Dynamic Count Data Model of Technological Innovations, Economic Journal 105, 333-344.

Bond, S., D. Harhoff and J. van Reenen (1999), Investment, R\&D and Financial Constraints in Britain and Germany, Discussion Paper, Institute for Fiscal Studies, London.

Börsch-Supan, A. H. (1998), Capital Productivity and the Nature of Competition, Brookings Papers on Economic Activity: Microeconomics, 205-244.

Börsch-Supan, A. H. and F. J. Köke (2000), An Applied Econometrician's View of Empirical Corporate Governance Studies, unpublished manuscript, University of Mannheim and Centre for European Economic Research, Mannheim.

Börsch-Supan, A. H. and J. K. Winter (1999), Pension Reform, Corporate Governance, and Savings Behavior. Discussion Paper No. 99-48, Sonderforschungsbereich 504, University of Mannheim.

Cable, J. (1985), Capital Market Information and Industrial Performance: The Role of West German Banks, The Economic Journal 95, 118-132.

Caves, R. E. and D. R. Barton (1990), Efficiency in U.S. Manufacturing Industries, Cambridge.

Caves, R. E. (1992), Industrial Efficiency in Six Nations, Cambridge. 
Chevalier, J. (1995a), Capital Structure and Product-Market Competition: Empirical Evidence from the Supermarket Industry, American Economic Review 85(3), 415-435.

Chevalier, J. (1995b), Do LBO Supermarkets Charge More? An Empirical Analysis of the Effects of LBOs on Supermarket Pricing, Journal of Finance 50(4), 1095-1112.

Cubbin, J. and D. Leech (1983), The Effect of Shareholding Dispersion on the Degree of Control in British Companies: Theory and Measurement, Economic Journal 93, 351369.

Edwards, J. and K. Fischer (1994), Banks, Finance and Investment in Germany, Cambridge: Cambridge University Press.

Fama, Eugene F. and Michael C. Jensen (1983), Separation of Ownership and Control, Journal of Law \& Economics 26, 301-325.

Feldstein, M. and A. Samwick (1997), The Economics of Prefunding Social Security and Medicare Benefits, in: B. S. Bernanke and J. J. Rotemberg (eds.), NBER Macroeconomics Annual, 115-148.

Green, A. and D. Mayes (1991), Technical Inefficiency in Manufacturing Industries, Economic Journal 101, 523-538.

Harhoff, D. and T. Körting (1998), Lending Relationships in Germany: Empirical Evidence From Survey Data, Journal of Banking and Finance 22, 1317-1353.

Hart, O. D. (1983), The Market Mechanism as an Incentive Scheme, Bell Journal of Economics 14(3), 366-382.

Hermalin, B. E. (1992), The Effects of Competition on Executive Behavior, Rand Journal of Economics 23(3), 350-365.

Himmelberg, C. P., R. G. Hubbard and D. Palia (1999), Understanding the Determinants of Managerial Ownership and the Link Between Ownership and Performance, Journal of Financial Economics 53, 353-384.

Holmström, B. (1982), Moral Hazard in Teams, Bell Journal of Economics 13(3), 324-340.

Jensen, M. C. (1986), Agency Costs of Free Cash Flow, Corporate Finance, and Takeovers, American Economic Review 76, 323-329.

Köke, F. J. (1999), New Evidence on Ownership Structures in Germany, ZEW Discussion Paper No. 99-60, Centre for European Economic Research, Mannheim.

Kovenock, D. and G. Phillips (1997), Capital Structure and Product Market Behavior: An Examination of Plant Exit and Investment Decisions, Review of Financial Studies 10(3), 767-803.

Leech, D. and J. Leahy (1991), Ownership Structure, Control Type Classifications and the Performance of Large British Companies, Economic Journal 101, 1418-1437.

McKinsey Global Institute (1997), Removing Barriers to Growth and Employment in France and Germany, Washington, DC.

Monopolkommission (1996), Wettbewerbspolitik in Zeiten des Umbruchs - Hauptgutachten 1994/1995, Anlagenband, Baden-Baden. 
Mueller, D. C. and B. B. Yurtoglu (1998), Rates of Return: A Cross National Comparison, mimeo, Department of Economics, University of Vienna.

Nalebuff, B. J. and J. E. Stiglitz (1983), Information, Competition, and Markets, American Economic Review 73(2), 278-283.

Nibler, M. (1995), Bank Control and Corporate Performance in Germany: The Evidence, Working Paper No. 48, University of Cambridge.

Nickell, S. (1996), Competition and Corporate Performance, Journal of Political Economy 104(4), 724-746.

Nickell, S., D. Nicolitsas and N. Dryden (1997), What Makes Firms Perform Well?, European Economic Review 41, 783-796.

Nickell, S. and D. Nicolitsas (1999), How Does Financial Pressure Affect Firms?, European Economic Review 43, 1435-1456.

Nowak, E. (1998), Finance, Investment, and Firm Value in Germany and the U.S.: A Comparative Analysis, mimeo, University of Frankfurt.

Phillips, G. M. (1995), Increased Debt and Industry Product Markets. An Empirical Analysis, Journal of Financial Economics 37, 189-238.

Prowse, S. (1994), Corporate Governance in an International Perspective: A Survey of Corporate Control Mechanisms Among Large Firms in the United States, the United Kingdom, Japan, and Germany, Bank for International Settlements Paper 41, 6-79.

Scharfstein, D. (1988), Product-Market Competition and Managerial Slack, Rand Journal of Economics 19(1), 147-155.

Schmidt, K. (1997), Managerial Incentives and Product Market Competition, Review of Economic Studies 64, 191-213.

Shleifer, A. and R. W. Vishny (1997), A Survey of Corporate Governance, Journal of Finance 52(2), 737-783.

Short, H. (1994), Ownership, Control, Financial Structure and the Performance of Firms, Journal of Economic Surveys 8(3), 203-249.

Wadhwani, S. and M. Wall (1986), The U.K. Capital Stock: New Estimates of Premature Scrapping, Oxford Review of Economic Policy 2(3), 44-55.

Winter, J. K. (1999), Does Firms' Financial Status Affect Plant-level Investment and Exit Decisions? Discussion Paper No. 99-3, Center for Economic Studies, U.S. Bureau of the Census, Washington D.C.

Zingales, L. (1998), Survival of the Fittest or the Fattest? Exit and Financing in the Trucking Industry, Journal of Finance 53(3), 905-938. 
Figure 1

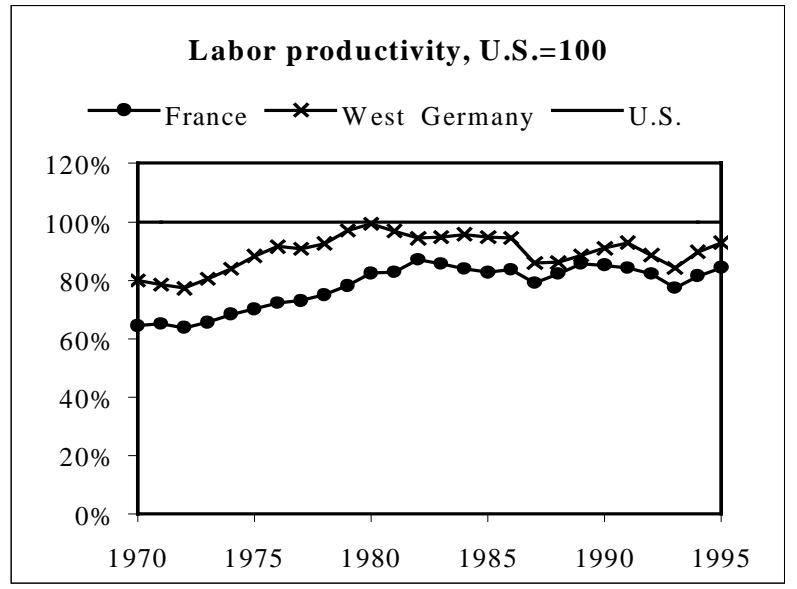

Figure 3

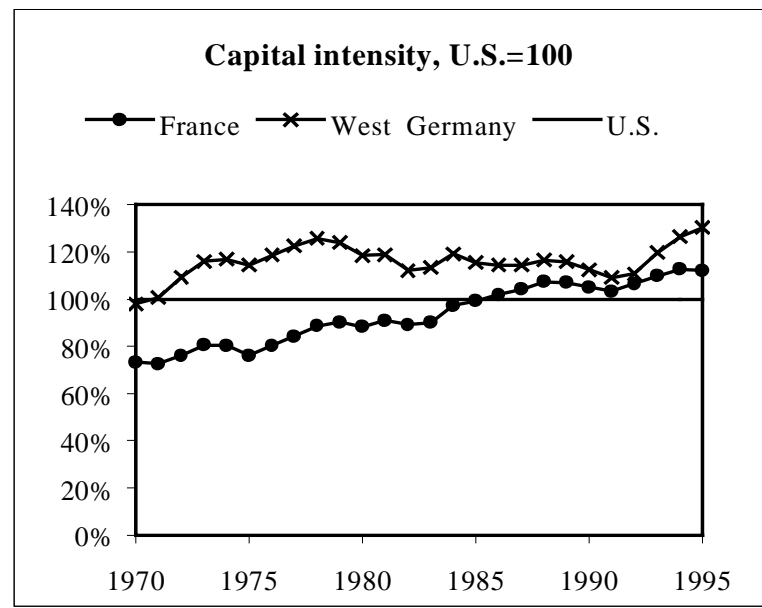

Figure 2

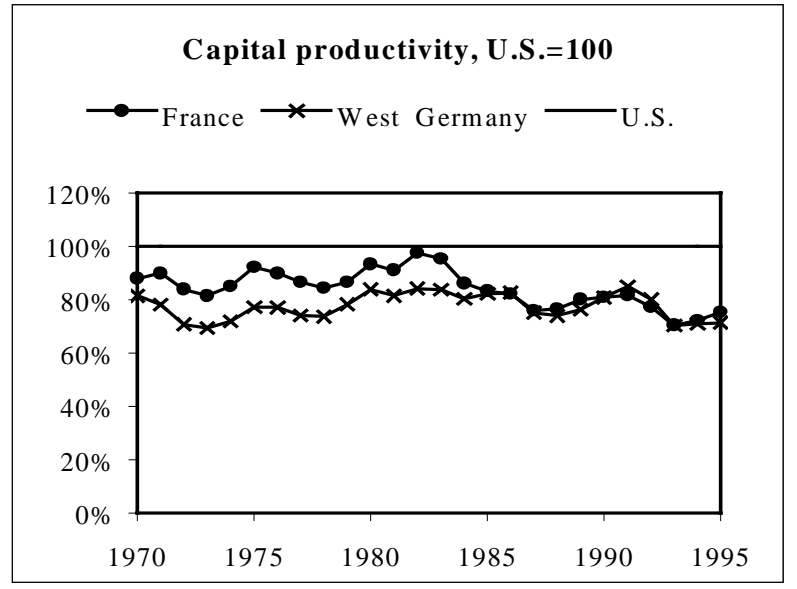

Figure 4

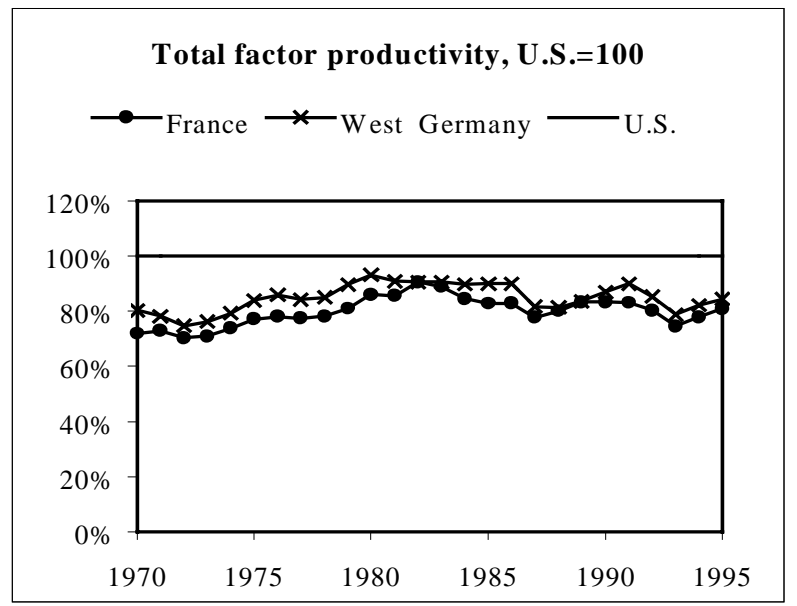

Source: Unpublished appendix to McKinsey Global Institute (1997). 
Table 1: Effects of competition on productivity growth

\begin{tabular}{|c|c|c|c|c|}
\hline \multirow[b]{2}{*}{ Variable } & \multicolumn{2}{|l|}{ Full sample } & \multicolumn{2}{|l|}{ Reduced sample } \\
\hline & $\begin{array}{l}\text { coefficient } \\
\text { (t-statistic) }\end{array}$ & $\begin{array}{l}\text { coefficient } \\
\text { (t-statistic) }\end{array}$ & $\begin{array}{l}\text { coefficient } \\
\text { (t-statistic) }\end{array}$ & $\begin{array}{l}\text { coefficient } \\
\text { (t-statistic) }\end{array}$ \\
\hline Constant & $\begin{array}{l}0.012 \\
(0.217)\end{array}$ & $\begin{array}{l}-0.087 \\
(0.687)\end{array}$ & $\begin{array}{l}-0.021 \\
(0.292)\end{array}$ & $\begin{array}{l}-0.017 \\
(0.081)\end{array}$ \\
\hline Sales (lagged) & $\begin{array}{l}0.439 \\
(5.338)\end{array}$ & $\begin{array}{l}0.337 \\
(3.911)\end{array}$ & $\begin{array}{l}0.313 \\
(2.484)\end{array}$ & $\begin{array}{l}0.218 \\
(1.822)\end{array}$ \\
\hline Labor - capital & $\begin{array}{l}0.529 \\
(5.951)\end{array}$ & $\begin{array}{l}0.595 \\
(6.409)\end{array}$ & $\begin{array}{l}0.593 \\
(4.273)\end{array}$ & $\begin{array}{l}0.689 \\
(5.922)\end{array}$ \\
\hline CR6 index (lagged) & & $\begin{array}{l}0.042 \\
(0.942)\end{array}$ & & $\begin{array}{l}0.023 \\
(0.289)\end{array}$ \\
\hline Cycle & & $\begin{array}{l}0.002 \\
(1.423)\end{array}$ & & $\begin{array}{l}0.001 \\
(0.252)\end{array}$ \\
\hline Rents (lagged) & & $\begin{array}{l}-0.099 \\
(3.401)\end{array}$ & & $\begin{array}{l}-0.094 \\
(2.072)\end{array}$ \\
\hline $\begin{array}{l}\text { Wald test (significance } \\
\text { of slope coefficients) }\end{array}$ & $\begin{array}{l}350.54 \\
d f=2, p=0.000\end{array}$ & $\begin{array}{l}423.74 \\
d f=5, p=0.000\end{array}$ & $\begin{array}{l}92.76 \\
\mathrm{df}=2, \mathrm{p}=0.000\end{array}$ & $\begin{array}{l}160.18 \\
d f=5, p=0.000\end{array}$ \\
\hline $\begin{array}{l}\text { Test for first-order } \\
\text { correlation of residuals }\end{array}$ & $\begin{array}{l}-2.697 \\
\mathrm{df}=328, \mathrm{p}=0.007\end{array}$ & $\begin{array}{l}-2.146 \\
\mathrm{df}=328, \mathrm{p}=0.032\end{array}$ & $\begin{array}{l}-2.260 \\
\mathrm{df}=138, \mathrm{p}=0.024\end{array}$ & $\begin{array}{l}-2.249 \\
\mathrm{df}=138, \mathrm{p}=0.025\end{array}$ \\
\hline $\begin{array}{l}\text { Test for second-order } \\
\text { correlation of residuals }\end{array}$ & $\begin{array}{l}-0.204 \\
\mathrm{df}=286, \mathrm{p}=0.838\end{array}$ & $\begin{array}{l}-0.249 \\
\mathrm{df}=286, \mathrm{p}=0.803\end{array}$ & $\begin{array}{l}-0.903 \\
\mathrm{df}=132, \mathrm{p}=0.367\end{array}$ & $\begin{array}{l}-0.895 \\
\mathrm{df}=132, \mathrm{p}=0.371\end{array}$ \\
\hline Sargan test & $\begin{array}{l}83.141 \\
d f=2, p=0.444\end{array}$ & $\begin{array}{l}96.072 \\
d f=87, p=0.237\end{array}$ & $\begin{array}{l}92.859 \\
d f=82, p=0.194\end{array}$ & $\begin{array}{l}102.575 \\
d f=87, p=0.122\end{array}$ \\
\hline
\end{tabular}

Source: Own calculations.

Notes: GMM estimation using the Arellano and Bond (1991) method. All regressions include a full set of time and industry dummies; Wald tests (not reported) do not reject joint significance of all dummies at the $1 \%$ level. 
Table 2: Effects of competition and ownership control on productivity

\begin{tabular}{|c|c|c|}
\hline \multirow[b]{2}{*}{ Variable } & \multicolumn{2}{|l|}{ Reduced sample } \\
\hline & $\begin{array}{l}\text { coefficient } \\
\text { (t-statistic) }\end{array}$ & $\begin{array}{l}\text { coefficient } \\
\text { (t-statistic) }\end{array}$ \\
\hline Constant & $\begin{array}{l}0.098 \\
(0.487)\end{array}$ & $\begin{array}{l}0.088 \\
(0.403)\end{array}$ \\
\hline Sales (lagged) & $\begin{array}{l}0.133 \\
(1.316)\end{array}$ & $\begin{array}{l}0.152 \\
(1.422)\end{array}$ \\
\hline Labor - capital & $\begin{array}{l}0.695 \\
(6.088)\end{array}$ & $\begin{array}{l}0.692 \\
(5.970)\end{array}$ \\
\hline CR6 index (lagged) & $\begin{array}{l}0.012 \\
(0.156)\end{array}$ & $\begin{array}{l}0.005 \\
(0.071)\end{array}$ \\
\hline Cycle & $\begin{array}{l}-0.001 \\
(0.345)\end{array}$ & $\begin{array}{l}0.000 \\
(0.156)\end{array}$ \\
\hline Rents (lagged) & $\begin{array}{l}-0.008 \\
(0.132)\end{array}$ & $\begin{array}{l}-0.075 \\
(1.468)\end{array}$ \\
\hline Rents * C99 (lagged) & $\begin{array}{l}-0.098 \\
(1.882)\end{array}$ & \\
\hline C99 & & $\begin{array}{l}-0.058 \\
(1.966)\end{array}$ \\
\hline $\begin{array}{l}\text { Wald test (significance } \\
\text { of slope coefficients) }\end{array}$ & $\begin{array}{l}147.83 \\
\mathrm{df}=6, \mathrm{p}=0.000\end{array}$ & $\begin{array}{l}149.27 \\
d f=6, p=0.000\end{array}$ \\
\hline $\begin{array}{l}\text { Test for first-order } \\
\text { correlation of residuals }\end{array}$ & $\begin{array}{l}-1.858 \\
\mathrm{df}=138, \mathrm{p}=0.063\end{array}$ & $\begin{array}{l}-1.934 \\
\mathrm{df}=138, \mathrm{p}=0.053\end{array}$ \\
\hline $\begin{array}{l}\text { Test for second-order } \\
\text { correlation of residuals }\end{array}$ & $\begin{array}{l}-0.909 \\
d f=132, p=0.363\end{array}$ & $\begin{array}{l}-0.894 \\
d f=132, p=0.371\end{array}$ \\
\hline Sargan test & $\begin{array}{l}97.511 \\
\mathrm{df}=86, \mathrm{p}=0.186\end{array}$ & $\begin{array}{l}99.120 \\
\mathrm{df}=86, \mathrm{p}=0.158\end{array}$ \\
\hline
\end{tabular}

Source: Own calculations.

Notes: GMM estimation using the Arellano and Bond (1991) method. All regressions include a full set of time and industry dummies; Wald tests (not reported) do not reject joint significance of all dummies at the $1 \%$ level. 
Table A1: Sample selection

Selection criteria

Observations

World-level consolidation

Full disclosure under new rules ( $\$ 289$ HGB)

Years 1986-1994

Firms with limited liability (AG, GmbH, GmbH \& Co. KG, KGaA)

Manufacturing industries

At least three consecutive observations

No missing data items

Source: Own calculations.

Table A2: Samples used for estimation

\begin{tabular}{lrr}
\hline & Firms & Observations \\
\hline Full sample & 364 & 2217 \\
- Aktiengesellschaft (AG) & 290 & 1803 \\
- Other (GmbH, GmbH \& Co. KG, KGaA) & 74 & 414 \\
\hline Subsample with ownership data & 136 & 935 \\
- Aktiengesellschaft (AG) & 130 & 893 \\
- Other (GmbH, GmbH \& Co. KG, KGaA) & 6 & 42 \\
\hline
\end{tabular}

Source: Own calculations.

Table A3: Number of observations per firm

\begin{tabular}{lrr}
\hline Observations per firm & Full sample & Reduced sample \\
\hline 3 & 108 & 21 \\
4 & 168 & 24 \\
5 & 320 & 85 \\
6 & 384 & 114 \\
7 & 483 & 238 \\
8 & 376 & 192 \\
9 & 378 & 261 \\
\hline Total & 2217 & 935 \\
Average number of observations & 6.63 & 7.29 \\
\hline
\end{tabular}

Source: Own calculations. 
Table A4: Number of observations by year

\begin{tabular}{lrr}
\hline Year & Full sample & Reduced sample \\
\hline 1986 & 57 & 34 \\
1987 & 122 & 61 \\
1988 & 189 & 94 \\
1989 & 251 & 112 \\
1990 & 310 & 125 \\
1991 & 337 & 131 \\
1992 & 344 & 131 \\
1993 & 315 & 126 \\
1994 & 292 & 121 \\
\hline Total & 2217 & 935 \\
\hline Source: Own calculation
\end{tabular}

Source: Own calculations.

Table A5: Descriptive statistics

\begin{tabular}{|c|c|c|c|c|}
\hline \multirow[b]{2}{*}{ Variable } & \multicolumn{2}{|l|}{ Full sample } & \multicolumn{2}{|l|}{ Reduced sample } \\
\hline & mean & st.d. & mean & st.d. \\
\hline$Y$ (million DM) & 3360 & 9020 & 3450 & 9580 \\
\hline$N$ (number of employees) & 12135 & 36439 & 12900 & 35000 \\
\hline$K($ million $\mathrm{DM})$ & 2900 & 9460 & 3360 & 11100 \\
\hline RENTS & 0.63 & 0.16 & 0.60 & 0.16 \\
\hline CYCLE & 0.86 & 0.05 & 0.86 & 0.05 \\
\hline CR6 & 0.42 & 0.25 & 0.42 & 0.24 \\
\hline$H H I$ & 0.00649 & 0.00771 & 0.00585 & 0.00735 \\
\hline CONTROL & & & 0.63 & 0.48 \\
\hline Number of observations & 2217 & & 935 & \\
\hline
\end{tabular}

Source: Own calculations.

Notes: In prices of 1991. 